\title{
PEMBELAJARAN BIOLOGI MELALUI INKUIRI TERBIMBING DAN INKUIRI BEBAS TERMODIFIKASI DITINJAU DARI KETERAMPILAN PROSES SAINS DAN KREATIVITAS SISWA
}

\author{
Dwijono \\ Guru biologi SMA Negeri 2 Madiun \\ dwijono_sma2@yahoo.com
}

\begin{abstract}
ABSTRAK
Penelitian ini bertujuan untuk mengetahui pengaruh pembelajaran biologi melalui inkuiri terbimbing dan inkuiri bebas termodifikasi, pengaruh keterampilan proses sains dan kreativitas serta interaksi diantara ketiganya terhadap prestasi belajar siswa. Penelitian ini menggunakan metode eksperimen dan dilaksanakan bulan September 2012 - Oktober 2012. Populasi adalah semua siswa kelas XII IPA SMAN 2 Madiun. Sampel penelitian diambil dengan metode cluster random sampling terdiri dari 2 kelas. Teknik pengumpulan data menggunakan metode tes untuk prestasi belajar kognitif dan kreativitas verbal serta metode angket untuk mengukur keterampilan proses sains serta metode observasi untuk data prestasi belajar afektif dan psikomotor. Teknik analisis data menggunakan analisis variansi dengan desain faktorial $2 \times 2 \times 2$ menggunakan software SPSS versi 16 dengan taraf signifikansi $5 \%$. Hasil pada penelitian ini adalah (1) terdapat perbedaan prestasi kognitif, afektif, dan psikomotor pada siswa yang belajar dengan pendekatan melalui inkuiri termbimbing dan inkuiri bebas termodifikasi (2) ada perbedaan antara siswa yang memiliki keterampilan proses sains tinggi dan rendah terhadap prestasi belajar kognitif, afektif, dan psikomotor (3) ada perbedaan antara siswa yang memiliki kreativitas tinggi dan rendah terhadap prestasi belajar kognitif, afektif, dan psikomotor (4) tidak terdapat interaksi terhadap prestasi belajar kognitif, afektif, dan psikomotor antara pembelajaran model inkuiri dengan keterampilan proses sains (5) terdapat interaksi prestasi kognitif dan tidak ada interaksi prestasi afektif dan psikomotor terhadap penggunaan model pembelajaran inkuiri dengan kreativitas siswa (6) terdapat interalsi antara keterampilan proses sains dengan kreativitas siswa terhadap prestasi afektif dan psikomotor (7) tidak ada interaksi antara model pembelajaran inkuiri, keterampilan proses sains dan kreativitas terhadap prestasi belajar siswa.
\end{abstract}

Kata Kunci : Inkuiri; Keterampilan Proses Sains; Kreativitas Verbal.

\section{PENDAHULUAN}

Pemerintah terus berupaya memenuhi hak setiap warga negara dalam memperoleh layanan pendidikan untuk meningkatkan kualitas hidup bangsa Indonesia. Maka pendidikan tidak hanya sekedar bertujuan membentuk manusia berpengetahuan, namun juga bertujuan untuk membentuk manusia yang mempunyai kecakapan hidup (life skill).

Karakteristik ilmu biologi dibangun melalui pengembangan keterampilan-keterampilan proses sains yaitu: (1) mengobservasi atau mengamati termasuk di dalamnya menghitung, mengukur, mengklasifikasi dan mencari hubungan ruang atau waktu; (2) menyusun hipotesis; (3) merencanakan eksperimen; (4) mengendalikan atau memanipulasi variabel; (5) menginterpretasikan atau menafsirkan data; (6) menyusun kesimpulan sementara; (7) meramalkan atau memprediksi; (8) menerapkan atau mengaplikasikan; (9) mengkomunikasikan (KTSP 2006).

Belajar merupakan kegiatan aktif siswa dalam membangun makna atau pemahaman dari suatu konsep. Dengan demikian guru perlu memberikan dorongan kepada siswa untuk menggunakan otoritasnya dalam membangun gagasan tanggung jawab pada diri siswa, tetapi guru bertanggung jawab kepada siswa untuk belajar sepanjang hayat. Hal ini sejalan dengan Bruner (dalam Dahar, 1986: 9) yang mengemukakan bahwa "Belajar melibatkan tiga proses yang berlangsung bersamaan. Ketiga 


\section{JEMS (Jurnal Edukasi Matematika dan Sains)}

Tersedia online di: http://e-journal.ikippgrimadiun.ac.id/index.php/JEMS

Volume 4, Nomor 2, September 2016, hal 66-75

proses itu ialah: (1) mengolah informasi baru, (2) transformasi informasi, dan (3) menguji relevansi dan ketepatan pengetahuan."

Sejalan dengan Permendiknas RI No. 22 tahun 2006 tentang paradigma pendidikan bahwa proses pembelajaran sesuai kurikulum KTSP mengalami perubahan yaitu dari "teaching" atau guru mengajar menjadi "learning" atau siswa belajar. Artinya, pusat pembelajaran era sekarang ini betul-betul terletak pada siswa. Guru sebagai fasilitator, motivator, administrator dalam proses pembelajaran dengan menggunakan metode yang tepat dengan karakteristik dan materi atau bahan ajar yang akan disajikan.

Dari hasil pengamatan bahwa faktor eksternal yang mempengaruhi antara lain penggunaan metode pembelajaran biologi yang masih belum mencerminkan proses sains. Pembelajaran biologi yang dapat digunakan antara lain metode eksperimen, demonstrasi, problem solving, inkuiri, discovery, penugasan, diskusi, dan lain-lain, akan tetapi masih ada guru yang kurang inovatif dalam melaksanakan kegiatan belajar mengajar di kelasnya, bahkan cenderung dengan metode ceramah.

Menurut Piaget (dalam Dahar, 1989: 149), pendekatan pembelajaran saat ini menekankan pada tujuan membelajarkan siswa secara maksimal sehingga suasana belajar di kelas menjadi kondusif untuk siswa yang pada akhirnya bermuara pada peningkatan prestasi belajar.

Penggunaan laboratorium biologi yang belum optimal yang disebabkan oleh alat dan bahan di laboratorium masih relatif kurang. Tenaga laboran belum ada. Belajar biologi masih berdasarkan buku tulis atau teori dan bahan berdasarkan eksperimen. Barlow (dalam Syah, 2005: 19) berpendapat bahwa kurang optimalnya belajar biologi juga dipengaruhi oleh faktor internal siswa antara lain kemauan dan kemampuan siswa maka belajar siswa belum diajak untuk melakukan kegiatan belajar siswa aktif. Keterampilan proses sains dan kreativitas verbal belum diperhitungkan secara optimal.

Pembelajaran biologi di SMA Negeri 2 Madiun menunjukkan kecenderungan yang sama dengan pembelajaran di Indonesia pada umumnya. Prestasi belajar biologi kelas XII IPA SMAN 2 Madiun materi metabolisma masih ada yang belum mencapai KKM. Dilihat dari target KKM tahun pelajaran 2009/2010 dan 2010/2011 rata-rata 75 dan KKM tahun pelajaran 2011/2012 nilai rata-rata 78, masih ada siswa yang belum tuntas rata-rata sebesar $23,2 \%$.

Untuk memecahkan masalah tersebut di atas maka seorang guru hendaknya tidak sekedar menyampaikan atau mentransfer informasi materi dari buku kepada peserta didik, tetapi siswa diajak memecahkan masalah tentang materi metabolisma dengan menggunakan model inkuiri yang mana siswa diberi masalah untuk dipecahkan bersama melalui eksperimen agar siswa dapat mendeskripsikan proses metabolisma karbohidrat.

Di samping menggunakan model inkuiri terbimbing (guided inquiry) daninkuiri bebas termodifikasi (modified free inquiry), peneliti juga mempraktekkan keterampilan proses sains dan kreativitas verbal untuk mencapai prestasi belajar siswa yang maksimal. Keterampilan proses sains dan kreativitas verbal sangat dibutuhkan dalam proses belajar mereka. Dengan demikian kedua faktor, baik internal yang berupa keterampilan proses sains, kreativitas verbal dan motivasi yang dimiliki siswa maupun faktor eksternal yang berupa model inkuiri, alat dan bahan laboratorium, LKS dapat dipadukan dalam proses pembelajaran di kelas dengan harapan dapat memacu prestasi belajar siswa.

Trowbridge and Bybee (dalam Suparno, 2001: 209) mengatakan, keterampilanketerampilan proses di atas harus ditumbuhkan dalam diri siswa SMA sesuai dengan taraf perkembangan pemikirannya. Keterampilanketerampilan ini akan menjadi roda penggerak penemuan dan pengembangan fakta dan konsep serta penumbuhan dan pengembangan sikap, wawasan dan nilai. Dengan kata lain, lulusan SMA diharapkan memiliki keterampilanketerampilan proses sains yang terhimpun dalam ilmu biologi. Salah satu standar kompetensi yang harus dikembangkan adalah mendemonstrasikan sikap ilmiah, kerja ilmiah dan komunikasi ilmiah dalam memecahkan masalah yang berkaitan dengan biologi. Kemudian mendeskripsikan sifat-sifat, metode pengukuran dan penerapannya yang dapat diperoleh melalui proses belajar di sekolah. 


\section{JEMS (Jurnal Edukasi Matematika dan Sains)}

Tersedia online di: http://e-journal.ikippgrimadiun.ac.id/index.php/JEMS

Volume 4, Nomor 1, Maret 2016, hal 66-75

Selain itu faktor internal yang tidak kalah penting yaitu kreativitas verbal. Siswa yang memiliki kreativitas verbal tinggi akan menghasilkan berbagai inovasi dan perkembangan baru. Individu yang kreatif akan selalu dibutuhkan oleh lingkungannya, mereka akan mampu bertahan dalam kompetisi global yang dinamis dan ketat.

Berdasarkan uraian latar belakang dan asumsi-asumsi yang ada, maka peneliti mengadakan penelitian tentang "Pembelajaran Biologi melalui Inkuiri terbimbing (guided inquiry) dan Inkuiri bebas termodifikasi (modified free inquiry) ditinjau dari keterampilan proses sains dan Kreativitas verbal." Penelitian ini bertujuan untuk mengetahui adanya (1) pengaruh penggunaan inkuiri terbimbing dan inkuiri bebas termodifikasi terhadap prestasi belajar siswa; (2) pengaruh keterampilan proses sains tinggi keterampilan proses sains rendah terhadap prestasi belajar siswa; (3) pengaruh kreativitas verbal tinggi dan kreativitas verbal rendah terhadap prestasi belajar siswa; (4) interaksi antara pendekatan melalui inkuiri terbimbing dan inkuiri bebas termodifikasi dengan keterampilan proses sains siswa terhadap prestasi belajar siswa; (5) interaksi melalui inkuiri terbimbing dan inkuiri bebas termodifikasi dengan kreativitas verbal terhadap prestasi belajar siswa; (6) interaksi keterampilan proses sains dengan kreativitas verbal terhadap prestasi belajar siswa; (7) interaksi melalui inkuiri terbimbing dan inkuiri bebas termodifikasi dengan sains serta kreativitas verbal terhadap prestasi belajar siswa.

\section{METODE PENELITIAN}

Penelitian ini dilakukan di SMA Negeri 2 Madiun April - November 2012 penelitian ini dilaksanakan dengan metode eksperimental. Sumber data yang digunakan merupakan sumber data primer karena penelitian memperoleh data langsung dari subjek penelitian.

Pada penelitian ini populasi yang diteliti adalah siswa kelas XII IPA SMA Negeri 2 Madiun di Kota Madiun tahun pelajaran 2012/2013 yang berjumlah 6 kelas dengan 196 siswa. Penarikan sampel menggunakan "Cluster Random Sampling" populasi dikelompokkan terlebih dahulu yaitu kelas XII $\mathrm{IPA}_{4}$, dan XII IPA 2 . Dalam penelitian ini tidak memilih individu secara langsung, tetapi melalui kelompok yang dipilih secara acak. Dari 2 kelompok (cluster) tersebut yang akan menggunakan pendekatan melalui inkuiri terbimbing adalah kelas XII IPA, satu kelas digunakan untuk pendekatan melalui inkuiri bebas termodifikasi adalah kelas XII IPA ${ }_{2}$.

Teknik pengambilan data dilakukan dengan pemberian tes, observasi, angket dan dokumentasi. Data prestasi belajar siswa diperoleh dari hasil tes yang diberikan kepada siswa setiap selesai proses pembelajaran berlangsung. Pada angket keterampilan proses sains dan kreativitas verbal diperoleh sebelum proses pembelajaran, bertujuan untuk mengetahui keterampilan proses sains dan kreativitas verbal yang dimiliki siswa. Sedangkan metode observasi dan dokumentasi diperoleh pada saat proses pembelajaran dan praktikum berlangsung. Metode observasi dilakukan untuk mengambil data prestasi afektif dan psikomotor.

Uji validitas pada tes prestasi kognitif dilakukan untuk mengetahui apakah alat evaluasi itu layak digunakan. Hasil soal kognitif uji coba kemudian dihitung daya beda soal, indeks kesukaran, validitas dan reliabilitas. Sedangkan tes keterampilan proses sains dan kreativitas siswa dihitung validitas dan reliabilitas.

Teknik analisis data pada penelitian ini terdiri dari uji prasyarat dan uji hipotesis. Pada uji prasyarat meliputi uji normalitas dan uji homogenitas. Uji normalitas menggunakan metode Kolmogorov Smirnov, sedangkan uji homogenitas dengan metode levenes test. Sedangkan pada uji hipotesis data penelitian menggunakan uji ANAVA Tests of BetweenSubjects Effects.

\section{HASIL PENELITIAN DAN PEMBAHASAN}

\section{Deskripsi Data Penelitian}

Data yang terkumpul dalam penelitian ini terdiri dari nilai prestasi siswa aspek kognitif, afektif, dan psikomotor pada materi metabolisma. Adapun rician prestasi belajar pada aspek kognitif, afektif, dan psikomotor dapat dilihat di bawah ini.

\section{Prestasi Belajar Biologi}

Pada penelitian ini nilai rata-rata prestasi belajar aspek kognitif, afektif, psikomotor pada 


\section{JEMS (Jurnal Edukasi Matematika dan Sains)}

Tersedia online di: http://e-journal.ikippgrimadiun.ac.id/index.php/JEMS

Volume 4, Nomor 2, September 2016, hal 66-75

pendekatan starter eksperimen melalui inkuiri terbimbing 83,$08 ; 71,81 ; 60,39$ sedangkan nilai rata-rata inkuiri bebas termodifikasi 80,36; 67,97 ; 56,41. Maka dapat dikatakan bahwa pendekatan melalui inkuiri terbimbing lebih baik daripada pendekatan melalui inkuiri bebas termodifikasi. Distribusi frekuensi nilai dan histogram prestasi belajar biologi yang menggunakan pendekatan melalui inkuiri terbimbing dan inkuiri bebas termodifikasi disajikan pada Gambar 1, 2, dan 3.

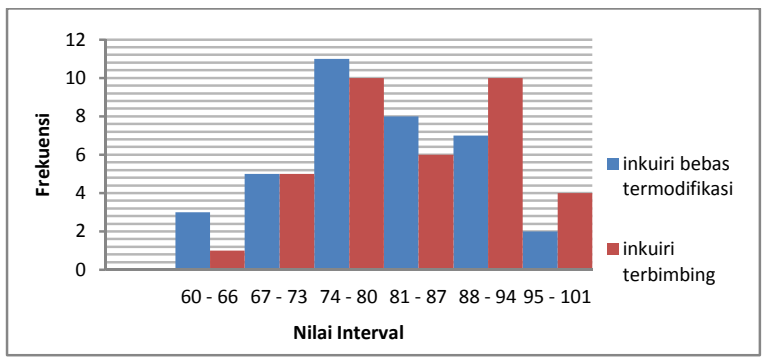

Gambar 1. Histogram Prestasi Kognitif

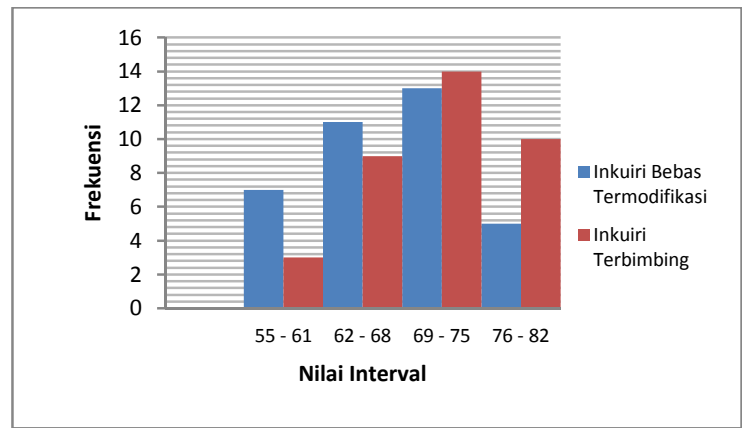

Gambar 2. Histogram Prestasi Afektif

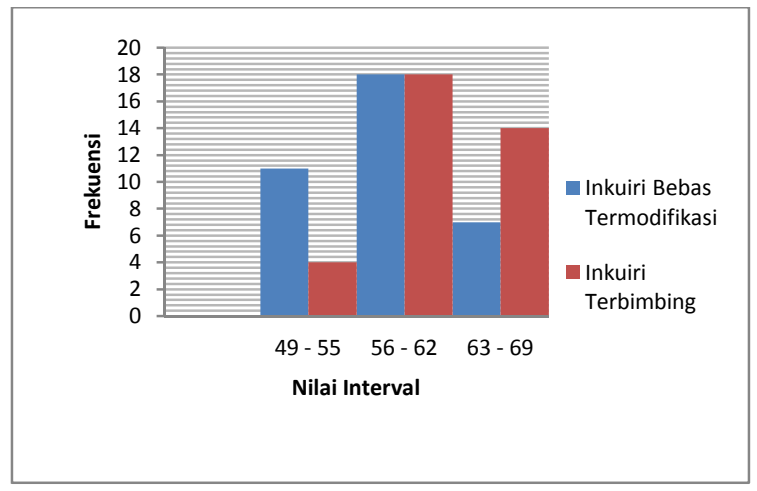

Gambar 3. Histogram Prestasi Psikomotor

\section{Uji Prasyarat dan Uji Hipotesis}

Hasil analisis variansi data prestasi belajar baik aspek kognitif, afektif, maupun psikomotor dapat disimpulkan sebagai berikut.

\section{Pengaruh Model}

Berdasarkan hasil penelitian bahwa ada perbedaan pendekatan melalui inkuiri terbimbing dan inkuiri bebas termodifikasi terhadap prestasi belajar pada aspek kognitif, afektif, dan psikomotor. Purwandari (2011) penggunaan pendekatan melalui inkuiri terbimbing dan inkuiri bebas termodifikasi, hendaknya dilakukan dengan persiapan yang matang, sehingga pembelajaran dapat berjalan lancar sesuai dengan rencanaHal ini dapat dilihat pada rata-rata nilai prestasi belajar pada kelas yang diberi model inkuiri terbimbing lebih tinggi dari model inkuiri bebas termodifikasi, pendekatan melalui inkuiri terbimbing dan inkuiri bebas termodifikasi memberikan adanya perbedaan kekuatan atau pengaruh dimana pendekatan melalui inkuiri terbimbing hasil rata-ratanya lebih besar dibandingkan dengan rata-rata pada pembelajaran inkuiri melalui inkuiri bebas termodifikasi. Hal ini menunjukkan bahwa pembelajaran melalui pembelajaran inkuiri 


\section{JEMS (Jurnal Edukasi Matematika dan Sains)}

Tersedia online di: http://e-journal.ikippgrimadiun.ac.id/index.php/JEMS

Volume 4, Nomor 1, Maret 2016, hal 66-75

melalui inkuiri terbimbing lebih baik pengaruhnya dibandingkan dengan pembelajaran inkuiri melalui terhadap penguasaan konsep metabolisma.

Pada proses pembelajaran dengan model inkuiri terbimbing dikelompokkan menjadi 5 kelompok kecil, mereka melakukan percobaan sendiri. Awal pembelajaran dimulai siswa diberikan suatu permasalahan tentang materi metabolisma. Pada model inkuiri terbimbing siswa menemukan sendiri konsep metabolisma dengan cara melakukan eksperimen kelompoknya sendiri. Setiap siswa diberikan LKS untuk menyusun dan mencatat proses eksperimen. Pada akhir pembelajaran setiap kelompok menyampaikan hasil analisanya kepada kelompok lain. Kemudian dari hasil analisa masing-masing kelompok ditarik suatu kesimpulan.

Pada proses belajar mengajar dikelas yang menerapkan model inkuiri bebas termodifikasi dibagi menjadi 5 kelompok. Model inkuiri bebas termodifikasi siswa diberikan permasalahan atau problematika tentang materi metabolisma dengan memberikan pertanyaan "bagaimana cara mahkluk hidup mendapat energi?". Kemudian siswa di arahkan untuk melakukan eksperimen tentang proses metabolisma. Pada proses pembelajaran siswa menemukan informasi dengan cara menyimpulkan sendiri proses eksperimen yang telah dilakukan. Sedangkan peran guru sebagai narasumber, pendorong dan memberikan bantuan demi kelancaran proses pembelajaran. Petunjuk yang diberikan guru hanya memberikan pertanyaan yang mengarahkan kepada pemecahan masalah yang dilakukan siswa. Hasil analisa masing-masing kelompok ditarik suatu kesimpulan. Siswa kelompok inkuiri bebas termodifikasi banyak mengalami kesulitan pada proses kesimpulan karena kurang terkonsep hasil pengamatan eksperimen tersebut.

Materi metabolisma merupakan materi hafalan yang memerlukan eksperimen dan banyak menggunakan aplikasi dalam kehidupan sehari-hari. Seperti halnya proses fotosintesis yang dilakukan daun hijau, proses fermentasi asam susu dan sebagainya. Materi metabolisma didominasi oleh praktikum. Oleh sebab itu, pendekatan melalui inkuiri terbimbing dan inkuiri bebas termodifikasi dapat meningkatkan prestasi siswa baik pada aspek kognitif, afektif, dan psikomotor. Pada proses inkuiri terbimbing siswa lebih terkonsep dalam menarik kesimpulan karena banyaknya informasi baik dari guru dan LKS. Pertanyaan yang sudah tersedia dalam LKS sangat membantu siswa untuk menemukan informasi tentang materi metabolisma. Sedangkan pada inkuiri bebas termodifikasi siswa cenderung merasa bingung dalam menarik suatu kesimpulan. Oleh karena itu, siswa yang diberi inkuiri terbimbing memperoleh rata-rata prestasi belajar lebih baik dibanding dengan siswa yang diberi inkuiri bebas termodifikasi. Hal ini sejalan dengan penelitian yang dilakukan oleh Özdilek dan Bulunuz (2009) menyatakan pembelajaran dengan inkuiri terbimbing lebih efektif dalam pembelajara IPA.

Berdasarkan penjelasan di atas dapat disimpulkan bahwa penggunaan model inkuiri terbimbing lebih baik daripada model inkuiri bebas termodifikasi pada materi gelombang terhadap prestasi belajar siswa aspek kognitif, afektif, dan psikomotor. Sejalan dengan penelitian Brickman (2009) mengungkapkan bahwa pembelajaran dengan model inkuiri dapat meningkatkan rasa percaya diri dan keterampilan sains. Pembelajaran yang dilakukan di laboratorium membuat siswa lebih percaya diri sehingga terjadi peningkatan prestasi belajar terutama pada materi IPA.

Pendekatan melalui inkuiri terbimbing dan inkuiri bebas termodifikasi menuntut siswa lebih aktif dalam menemukan materi metabolisma. Dalam hal ini guru berperan sebagai pendorong untuk menemukan informasi. Hal ini sesuai dengan pernyataan yang diungkapkan oleh Opara dan Oguzor (2011), bahwa pembelajaran inkuiri, peran guru hanya sebagai pendorong siswanya untuk menemukan ide-ide untuk diri mereka sendiri dan untuk belajari lmu-ilmu dengan mengembangkan, sejauh mungkin ilmu pengetahuan. Sehingga penggunaan melalui inkuiri terbimbing dan inkuiri bebas termodifikasi sangat besar pengaruhnya terhadap prestasi kognitif, afektif, dan psikomotor.

\section{Pengaruh Keterampilan Proses Sains}

Berdasarkan hasil penelitian bahwa ada perbedaan keterampilan proses sains terhadap prestasi belajar siswa kognitif, afektif, dan psikomotor. Keterampilan proses sains siswa baik tinggi maupun rendah memberikan pengaruh yang signifikan terhadap prestasi 


\section{JEMS (Jurnal Edukasi Matematika dan Sains)}

Tersedia online di: http://e-journal.ikippgrimadiun.ac.id/index.php/JEMS

Volume 4, Nomor 2, September 2016, hal 66-75

belajar kognitif, afektif, dan psikomotor. Hal ini berarti bahwa dalam proses pembelajaran faktor keterampilan proses sains siswa menunjang keberhasilan dalam prestasi siswa khususnya materi metabolisma.

Tingkat keterampilan proses sains siswa pada penelitian ini diketahui memberikan efek berbeda terhadap pencapaian prestasi belajar biologi pada hasil uji anava tiga jalan, hasil uji lanjutnya memberikan informasi dimana siswa yang memiliki tingkat keterampilan proses sains tinggi mendapatkan rata-rata prestasi lebih tinggi dari siswa yang memiliki tingkat keterampilan proses sains rendah. Keterampilan proses sains merupakan keseluruhan keterampilan ilmiah yang terarah (baik kognitif maupun psikomotor) yang dapat digunakan oleh yang bersangkutan untuk menemukan suatu konsep atau prinsip atau teori untuk mengembangkan konsep yang ada sebelumnya. Pada prestasi belajar afektif dapat dilihat pada saat melakukan praktikum di kelas, siswa yang lebih teliti, rajin dan objektif dalam mengamati dan menarik suatu kesimpulan. Pada saat praktikum tidak ada siswa yang diam dan mengantuk karena semua siswa mempunyai keinginan untuk aktif ikut serta dalam pembelajaran. Peran guru menjadi kurang dominan, guru hanya memberikan penjelasan akhir atas diskusi yang telah dilakukan.

Pada tahun 1970, The Lomission of Professional Standards and Practices of National Science Teachers Association di Amerika mengatakan bahwa pengalaman siswa dalam situasi laboratorium seharusnya menjadi bagian integral dari mata pelajaran sains (Hofs Lein dan Inneta, 1982). Pernyataan tersebut menunjukkan bahwa kegiatan laboratorium mempunyai peranan penting dalam pengajaran sains.

Siswa yang mempunyai keterampilan proses sains lebih mampu memahami mata pelajaran biologi terutama pada materi metabolisma. Pada materi metabolisma, siswa dituntut paham tentang proses-proses metabolisma pada makhluk hidup, seperti proses fotosintesis. Pada pelajaran biologi terutama materi metabolisma lebih menekankan pada praktikum. Siswa yang mempunyai teliti, kreatif, tekun, tenggang rasa, bertanggung jawab, kritis, objektif, rajin, jujur, terbuka dan disiplin yang tinggi dapat mengembangkan pelajaran biologi dengan lebih memahami praktikum yang telah dilakukan. Hal ini keterampilan ini dapat digunakan sebagai wahana penemuan dan pengembangan konsep yang telah ditemukan atau dikembangkan dengan pengembangan keterampilan proses sains itu sendiri.

Siswa yang mempunyai keterampilan proses sains cenderung lebih mandiri dalam belajar. Dalam melakukan suatu praktikum, siswa yang mempunyai keterampilan proses sains tinggi lebih mampu menyimpulkan apa yang diamati tanpa diberi petunjuk oleh guru. Sedangkan siswa yang mempunyai keterampilan proses sains rendah, mereka terbantu dengan adanya LKS sehingga proses penarikan kesimpulan dapat sesuai dengan yang diharapkan. Hal ini sejalan dengan Mei (2007) mengemukakan bahwa siswa yang mandiri dalam pembelajarannya mempunyai keterampilan proses sains yang tinggi. Siswa yang mempunyai keterampilan proses sains, belajarnya lebih terarah dan pengembangan konsepnya lebih luas. Berdasarkan pernyataan di atas bahwa keterampilan proses sains sangat besar pengaruhnya terhadap prestasi kognitif, afektif, dan psikomotor.

\section{Pengaruh Kreativitas Verbal Siswa}

Ada perbedaan kreativitas verbal kategori tinggi dan rendah terhadap prestasi belajar siswa. Hasil uji lanjut dan analisis rata-rata diperoleh informasi bahwa siswa dengan kreativitas verbal tinggi cenderung mendapatkan prestasi yang lebih tinggi dibandingkan dengan siswa yang memiliki kreativitas verbal rendah.

Pengertian kreativitas dapat dijelaskan melalui berbagai dimensi antara lain dimensi pribadi (person), dimensi proses, dimensi produk dan dimensi pendorong (person). Berpikir kreatif menurut Lawson (1980) dimaknai suatu proses kreatif.

Kreativitas merupakan kemampuan siswa dalam mendapat suatu informasi yang telah diperoleh sebelumnya sehingga dapat memecahkan masalah dengan menemukan banyak kemungkinan jawaban. Siswa yang mempunyai kreativitas verbal yang tinggi mampu mengolah informasi dari guru yang kemudian dikembangkan lagi dalam bentuk informasi yang lain. Siswa yang mempunyai kreativitas verbal tinggi lebih antusias dalam pembelajaran dan praktikum, karena mereka 


\section{JEMS (Jurnal Edukasi Matematika dan Sains)}

Tersedia online di: http://e-journal.ikippgrimadiun.ac.id/index.php/JEMS

Volume 4, Nomor 1, Maret 2016, hal 66-75

sangat tertarik pada tugas-tugas yang diberikan guru dan menganggap tugas tersebut sebagai suatu tantangan. Sedangkan pada siswa yang mempunyai kreativitas verbal rendah cenderung diam dan mudah bosan dengan proses pembelajaran. Sehingga dapat diketahui bahwa kreativitas verbal merupakan faktor internal yang sangat berpengaruh terhadap prestasi belajar baik pada aspek kognitif, afektif, maupun psikomotor. Siswa yang mempunyai kreativitas verbal tinggi memperoleh prestasi belajar lebih tinggi dibanding dengan siswa yang mempunyai kreativitas verbal rendah.

\section{Interaksi Model Keterampilan Proses Sains dan Kreativitas Verbal Siswa}

Berdasarkan hasil hasil penelitian bahwa tidak ada interaksi pendekatan melalui inkuiri terbimbing dan inkuiri bebas termodifikasi dengan keterampilan proses sains terhadap prestasi belajar pada aspek kognitif, afektif, dan psikomotor.

Keterampilan proses sains sangat berkaitan dengan proses saat melakukan praktikum. Siswa pada proses praktikum baik menggunakan inkuiri terbimbing atau inkuiri bebas termodifikasi, siswa dituntut melakukan praktikum sesuai dengan perintah atau informasi yang telah diberikan guru baik dalam wujud LKS maupun keterangan. Sehingga ini dapat disimpulkan bahwa interaksi antara pembelajaran inkuiri melalui inkuiri terbimbing dan inkuiri bebas termodifikasi dengan keterampilan proses sains siswa tidak memberikan pengaruh yang signifikan terhadap prestasi belajar kognitif, afektif, dan psikomotor. pada materi metabolisma. Artinya tingkat keterampilan proses sains dan penggunaan pendekatan melalui inkuiri terbimbing dan inkuiri bebas termodifikasi mempunyai pengaruh yang hampir sama terhadap prestasi belajar pada materi metabolisma. Hal ini dimungkinkan karena banyak faktor yang dapat mempengaruhi proses pencapaian prestasi belajar baik dalam maupun luar diri siswa diluar faktor metode, dan keterampilan proses sains siswa yang digunakan dalam penelitian ini, serta masih banyak keterbatasan dalam penelitian ini sehingga tidak dapat mengontrol faktor-faktor tersebut di luar kegiatan belajar mengajar.

\section{Interaksi Model Keterampilan Proses Sains}

Tidak ada interaksi antara pendekatan melalui inkuiri terbimbing dan inkuiri bebas termodifikasi dengan kreativitas verbal tinggi dan rendah terhadap prestasi belajar kognitif. Interaksi antara pendekatan melalui inkuiri terbimbing dan inkuiri bebas termodifikasi memberikan pengaruh yang signifikan terhadap prestasi belajar afektif dan psikomotor.

Pada saat praktikum berlangsung terlihat bahwa pendekatan melalui inkuiri terbimbing dan inkuiri bebas termodifikasi, siswa memiliki kreativitas verbal tinggi dan rendah mempunyai nilai rata-rata prestasi kognitif yang tidak jauh berbeda. Saat berdiskusi, siswa yang memiliki kreativitas verbal tinggi menyampaikan informasi dengan cara yang kreatif seperti dengan menampilkan gambar, sehingga siswa lain dapat menerima informasi dengan baik. Hal ini memungkinkan bahwa siswa yang mempunyai kreativitas verbal rendah dapat mengerjakan tes kognitif dengan perbedaan nilai rata-rata yang tidak signifikan.

Siswa yang diberi inkuiri terbimbing mempunyai kreativitas verbal tinggi memperoleh nilai rata-rata prestasi afektif dan psikomotor paling tinggi. Hal ini terlihat pada saat proses inkuiri terbimbing baik pada saat praktikum maupun berdiskusi. Siswa yang mempunyai kreativitas verbal tinggi mampu menangkap informasi yang disampaikan guru ataupun LKS ke dalam informasi dengan bentuk lain. Sedangkan pada saat inkuiri bebas termodifikasi siswa yang mempunyai kreativitas verbal kurang begitu memahami informasi yang diberikan guru pada saat praktikum, jadi pada saat proses menarik kesimpulan siswa hanya mampu menyampaikan apa yang diinformasikan dari guru.

Perbedaan nilai rata-rata prestasi afektif yang signifikan terjadi pada siswa yang mempunyai kreativitas verbal tinggi pada inkuiri terbimbing dengan siswa yang mempunyai kreativitas verbal tinggi pada inkuiri bebas termodifikasi, siswa yang mempunyai kreativitas verbal tinggi dengan rendah pada kelas inkuiri terbimbing, dan siswa yang mempunyai kreativitas verbal tinggi pada inkuiri terbimbing dengan siswa yang mempunyai kreativitas verbal rendah pada inkuiri bebas termodifikasi.

Pada prestasi aspek psikomotor, pada kelas inkuiri terbimbing siswa yang mempunyai kreativitas verbal tinggi lebih cermat dan antusias dalam menangkap setiap informasi 


\section{JEMS (Jurnal Edukasi Matematika dan Sains)}

Tersedia online di: http://e-journal.ikippgrimadiun.ac.id/index.php/JEMS

Volume 4, Nomor 2, September 2016, hal 66-75

yang ada. Sedangkan pada kelas inkuiri bebas termodifikasi siswa yang mempunyai kreativitas verbal tinggi juga mampu mengolah informasi yang ada ke konsep lain yang sesuai dengan materi metabolisma, tetapi semua informasi yang didapat belum bisa tersaji dengan jelas. Sehingga pada kelas inkuiri bebas termodifikasi perlu adanya bimbingan yang intensif dari guru. Hal ini dapat disimpulkan bahwa adanya interaksi pendekatan starter eksperimen melalui inkuiri terbimbing dan inkuiri bebas termodifikasi dengan kreativitas verbal (tinggi dan rendah) memberikan pengaruh yang signifikan terhadap prestasi psikomotor.

\section{Interaksi Model Kreativitas Verbal Siswa}

Tidak ada interaksi kemampuan berpikir abstrak dan kongkret dengan keterampilan proses sains terhadap prestasi belajar siswa pada aspek afektif dan psikomotor. Berdasarkan hasil analisis siswa yang mempunyai kreativitas verbal tinggi atau rendah dan siswa yang mempunyai keterampilan proses sains tinggi atau rendah memperoleh prestasi belajar yang hampir sama.

Prestasi belajar pada aspek kognitif, siswa yang mempunyai keterampilan proses sains tinggi lebih mampu memahami dan menyimpulkan materi metabolisma pada saat proses pembelajaran inkuiri terbimbing dan inkuiri bebas termodifikasi berlangsung. Pada saat tes kognitif, siswa yang mempunyai keterampilan proses sains tinggi dan kreativitas verbal tinggi mampu menyelesaikan tes kognitif dengan baik. Hal ini terlihat bahwa siswa yang mempunyai keterampilan proses sains tinggi dan kreativitas verbal tinggi memperoleh hasil rata-rata prestasi kognitif tertinggi.

Prestasi belajar afektif dan psikomotor terlihat pada saat proses praktikum, baik siswa yang bekerja dengan sebaik-baiknya demi kelompoknya. Siswa yang mempunyai keterampilan proses sains tinggi dan kreativitas verbal tinggi mampu memberikan informasi yang berbeda ke siswa yang lain. Sedangkan siswa yang mempunyai keterampilan proses sains rendah dan kreativitas verbal rendah juga mampu melakukan praktikum dengan sebaik mungkin. Adanya kerjasama antar kelompok dalam melakukan praktikum ataupun diskusi, sehingga dapat disimpulkan bahwa, ada interaksi antara keterampilan proses sains dengan kreativitas terhadap prestasi belajar afektif dan psikomotor pokok materi metabolisma. Artinya tingkat keterampilan proses sains dan kreativitas verbal mempunyai pengaruh yang tidak signifikan terhadap prestasi belajar Biologi.

\section{Interaksi Keterampilran Proses Sains dan Kreativitas Verbal Siswa}

Ada interaksi antara pendekatan melalui inkuiri terbimbing dan inkuiri bebas termodifikasi dengan keterampilan proses sains (tinggi dan rendah) dan kreativitas verbal (tinggi dan rendah) terhadap prestasi belajar kognitif, afektif, dan psikomotor.

Siswa yang mempunyai keterampilan proses sains tinggi dan kreativitas verbal tinggi memperoleh nilai rata-rata prestasi kognitif, afektiif dan psikomotor paling tertinggi, hal ini berlaku pada kelas inkuiri terbimbing dan inkuiri bebas termodifikasi. Pada kelas inkuiri terbimbing dengan inkuiri bebas termodifikasi, nilai rata-rata prestasi belajar siswa yang mempunyai keterampilan tinggi dan kreativitas verbal tinggi yang paling baik yaitu pada kelas inkuiri terbimbing. Hal ini dapat dilihat bahwa setiap siswa yang mempunyai keterampilan proses sains (tinggi dan rendah) dan kreativitas verbal (tinggi dan rendah) masih perlu bimbingan yang banyak dan siswa harus lebih kreatif untuk mendapatkan informasi bukan hanya berasal dari guru, buku paket dan LKS, siswa dapat mengkaitkannya dengan kehidupan sehari-hari.

Dapat disimpulkan bahwa tidak terjadi interaksi antara model pembelajaran, keterampilan proses sains dan kreativitas verbal terhadap prestasi belajar biologi pokok bahasan metabolisma. Artinya tingkat keterampilan proses sains, tingkat kreativitas verbal dan penggunaan pendekatan melalui inkuiri terbimbing dan inkuiri bebas termodifikasi mempunyai pengaruh sendiri-sendiri terhadap prestasi belajar biologi pokok materi metabolime. Hal ini dimungkinkan karena banyak faktor yang dapat mempengaruhi proses pencapaian prestasi belajar (kognitif, afektif, dan psikomotor) baik dalam maupun luar diri siswa diluar faktor metode pembelajaran, keterampilan proses sains dan kreativitas verbal yang digunakan dalam penelitian ini, serta masih banyak keterbatasan dalam penelitian ini sehingga peneliti tidak dapat mengontrol faktor- 


\section{JEMS (Jurnal Edukasi Matematika dan Sains)}

Tersedia online di: http://e-journal.ikippgrimadiun.ac.id/index.php/JEMS

Volume 4, Nomor 1, Maret 2016, hal 66-75

faktor tersebut di luar kegiatan belajar mengajar.

\section{KESIMPULAN DAN REKOMENDASI}

Berdasarkan hasil analisis dan pengujian hipotesis yang telah dipaparkan, dapat disimpulkan (1) pendekatan melalui inkuiri terbimbing dan inkuiri bebas termodifikasi memberikan adanya perbedaan kekuatan atau pengaruh dimana inkuiri terbimbing hasil rataratanya lebih besar dibandingkan dengan ratarata pada inkuiri bebas termodifikasi. (2) keterampilan proses sains siswa baik tinggi maupun rendah memberikan pengaruh yang signifikan terhadap prestasi belajar kognitif, afektif, dan psikomotor. (3) siswa yang mempunyai keterampilan tinggi lebih memberikan pengaruh yang signifikan terhadap prestasi kognitif, afektif, dan psikomotor. (4) siswa yang mempunyai tingkat keterampilan proses sains dengan pendekatan melalui inkuiri terbimbing dan inkuiri bebas termodifikasi mempunyai pengaruh sendiri-sendiri terhadap prestasi kognitif, afektif, dan psikomotor. (5) tingkat kreativitas verbal dengan pendekatan melalui inkuiri terbimbing dan inkuiri bebas termodifikasi mempunyai pengaruh yang signifikan terhadap prestasi afektif dan psikomotor. (6) tingkat keterampilan proses sains dengan kreativitas verbal mempunyai pengaruh signifikan terhadap prestasi belajar biologi aspek kognitif pada materi metabolisma. (7) tingkat pendekatan starter eksperimen melalui inkuiri terbimbing dan inkuiri bebas termodifikasi dengan keterampilan preses dan krativitas mempunyai pengaruh sendiri-sendiri terhadap prestasi belajar biologi.

- Beberapa hal yang perlu disiapkan dalam penggunaan pendekatan melalui inkuiri terbimbing dan inkuiri bebas termodifikasi antara lain: (1) menyiapkan dan mengecek alat dan bahan untuk melakukan praktikum, (2) menyiapkan LKS dengan sintaks inkuiri dan sumber informasi lain yang dapat mempermudah siswa dalam memahami konsep.

Perlu dilakukan penelitian tentang faktorfaktor lain yang berpengaruh terhadap prestasi belajar, sehingga dapat menambah pengetahuan guru dalam upaya meningkatkan prestasi belajar siswa.

Guru harus memberi tes awal sebelum pembelajaran dimulai, bagi siswa yang memiliki minat belajar rendah maka harus dilaksanakan remedial, agar minat belajarnya menjadi tinggi.

Hasil penelitian ini dapat digunakan sebagai acuan untuk penelitian-penelitian berikutnya yang sejenis dan hasil penelitian ini diharapkan dapat memberikan kontribusi bagi perkembangan ilmu pengetahuan pada khususnya pada mata pembelajaran materi metabolisma.

\section{DAFTAR PUSTAKA}

Brickman. Peggy. At al. (2009). Effects of Inquiry-based Learningon Students' Science Literacy Skills and Confidence. International Journal for the Scholarship of Teaching and Learning. Vol. 3 No. (2), (Juli 2009).

Hodson. D. (1996). Practical Work in School Science: Exploring Some Directions for Charge. International Journal of Science Education. 14 (11): 541-563.

Holstein. A and Lunetta. Vincent. N. (1962). The Role of Laboratory in Science Teaching Negleted Aspect of Research: Review of Educational Research. 52 (2): 201-207.

Mei. (2007). Promoting Science Process Skills and The Relevance of Science Through Science Alive! Programme. Singapore: Clementi Town Secondary School.

Munandar. U. (1999). Pengembangan Kreativitas Anak Berbakat. Jakarta: Rineka Cipta.

Nur. M. (2011). Modul Keterampilanketerampilan Proses Sains. Edisi Pertama. Universitas Negeri Surabaya. Pusat Sains dan Matematika Sekolah (PSMS).

Nuryani. R. Andrian. R. (1997). Pokok-pokok Pengajaran Biologi dan Kurikulum 1994. Jakarta: Pusbuk Depdikbud.

Opara dan Oguzor. (2011). Inquiry Instructional Method and the School Science Currículum. Current Research Journal of Social Sciences. 3 (3): 188-198. 
JEMS (Jurnal Edukasi Matematika dan Sains)

Tersedia online di: http://e-journal.ikippgrimadiun.ac.id/index.php/JEMS

Volume 4, Nomor 2, September 2016, hal 66-75

Özdilek dan Bulunuz. (2009). The Effect of a Guided Inquiry Method on Pre-service Teachers' Science Teaching SelfEfficacy Beliefs. Journal of Turkish Science Education. 6 (2): 24-42.

Peraturan Pemerintah Republik Indonesia No. 19 Tahun 2005 tentang Standar Nasional. Jakarta.

Purwandari, P., Huriawati, F., \& Yusro, A. C. (2015). Efektifitas Inquiry Terbimbing Dan Inquiry Bebas Termodifikasi Melalui Eksperimen Terhadap Hasil Belajar Fisika Ditinjau Dari Kemampuan Awal, Kreatifitas, Kemampuan Berpikir Abstrak Siswa Kelas X SMA Negeri 6 Kota Madiun Tahun Ajaran 2010/2011. Jurnal Pendidikan, 18(1).

Sund. R.B. dan Trowbridge. L.W. (1973). Teaching Science by Inquiry in The Secondary School. Second Edition.
Colombus: Charles E. Merril Publishing Company.

Suparno. P. (1997). Filsafat Konstruktivisme dalam Pendidikan. Yogyakarta: Penerbit Kanisius. . (2005). Teori Perkembangan Kognitif Jean Piaget. Yogyakarta: Penerbit Kanisius.

Trowbridge. and Bybee. (1991). Becoming a Secondary School Science Teacher. Colombus: Merrill Publishing Company. 